Our Nature 2013, 11(2): 201-207

\title{
Diversity of Snakes in Sarlahi District, Nepal
}

\author{
Krishna Chettriand Damodar Thapa Chhetry* \\ Department of Zoology, Post Graduate Campus,T.U. Biratnagar, Nepal \\ *Email: thp.damodar7@gmail.com \\ Received: 25.11.2013; Accepted: 20.12.2013
}

\begin{abstract}
A total of 21 snake species belonging to 17 genera and 4 families were recorded. Out of 21 species, 2, 14, 4, and 1 belong to family Typhlopidae, Colubridae, Elapidae and Viperidae respectively. They have been categorized as deadly venomous, mild venomous and non-venomous. Among the recorded species 5 were deadly venomous, 4 were mild venomous and the remaining 12 were non venomous. The species of Boidae family was not encountered during the study period.
\end{abstract}

Key words: Snakes diversity, venomous snakes, Sarlahi District

\section{Introduction}

Nepal is unique in geographically, culturally as well as in terms of vegetation and animal diversity. Nepal's rich biodiversity is a reflection of its unique geographical position as well as its altitudinal and climatic variations. The herpetofauna has a wide range of vertical $(60 \mathrm{~m}-5490 \mathrm{~m})$ and horizontal in distribution. The field of herpetology has always received less priority in Nepal. Scientific investigations concerning the herpetofauna of Nepal have been sporadic and so the information related to the subject is scanty. The first zoogeographical analysis of Nepalese herpetofauna was done by Swan and Leviton (1962) which laid a good basis for further studies. In recent years several herpetologists like Fleming and Fleming (1974), Kramer (1977), Joshi (1985), Nanhoe and Ouboter (1987), Shah and Giri (1991), Schleich (1993), Shah (1995, 1997), Orlov and Helfenberger (1997),Schleich and Kastle (2002), Shah et al. (2003), Shah and Tiwari (2004) have given important contribution on the study of snake fauna in Nepal. Sarlahi is one of the small districts of Nepal having 1259 sq. $\mathrm{km}$ in area. Geographically, it is divided into three regions, Churia hills in the north, Bhawar in the middle and Terai in south. It lies in the Central Development Region of Nepal having the height range from $60 \mathrm{~m}$ to $659 \mathrm{~m}$ above the sea level. The border lines of this district are Hardinath River in the east and Bagmati River in the west. It occupies $0.86 \%$ of the total land area of Nepal. Most of the people of this district are poor, illiterate and involved mainly in agricultural activities.

\section{Description of study areas}

For the collection of snake species from different areas of Sarlahi district, three study sites were undertaken, viz., Site I Lalbandi, Site II - Hariwon and Site III Karmaya (Fig. 1).

\section{Site I - Lalbandi}

Lalbandi is in the north-east of Sarlahi district. It is bordered by Dhalkaber Fuljorbaba jungle, Churia hills and open 


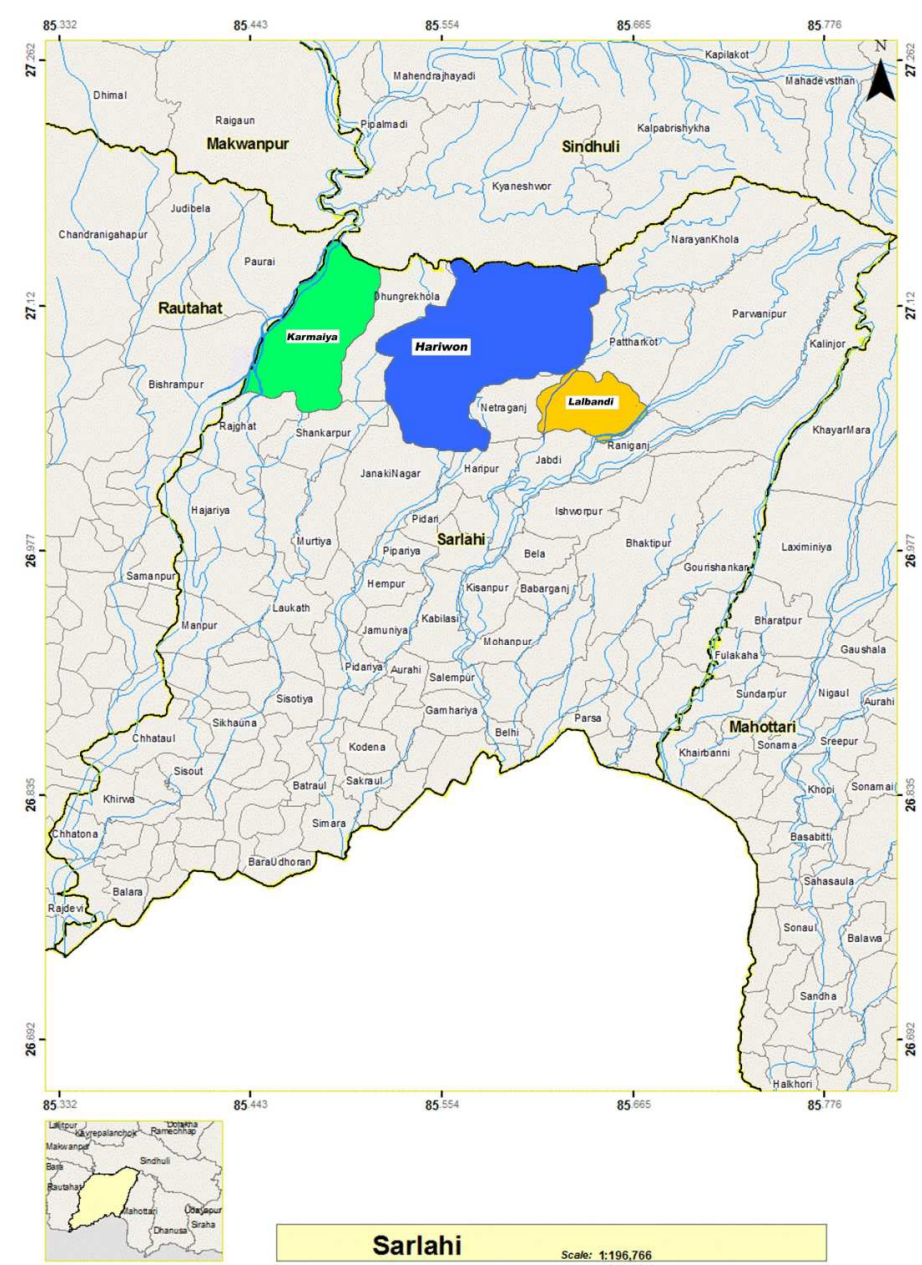

Figure 1. Map of Sarlahi District showing the three study sites.

plain agricultural land in the east, north, and south respectively. It lies between $27^{0} 03^{\prime}$ $01.80^{\prime \prime}$ to $27^{0} 03^{\prime} 20.68 \mathrm{~N} \mathrm{~N}$ latitude and $85^{\circ}$ $38^{\prime} 34.97 "$ to $85^{\circ} 37^{\prime} 27.81^{\prime \prime}$ E longitude. Its elevation is $489 \mathrm{ft}$. Most of this VDC is occupied by open plain agricultural land. For the cultivation of vegetables, Lalbandi is famous in Nepal. This VDC is a pocket area for tomato cultivation in the nation. In the north of this VDC, there is a small pocket of forest named Lalbandi forest having the area of 1940 hectors. The main trees of this forest are Sal (Shorea robusta), Khayar (Acacia catechu), Satvir (Asparagus recemosus), etc.

\section{Site II -Hariwon}

Hariwon is a new Municipality formed by the combination of four VDC like Hariwon, Aatroli, Sasapur and Ghudkhauli. It lies between $27^{0} 05^{\prime} 07.53^{\prime \prime}$ to $27^{0} 06^{\prime} 02.56 " \mathrm{~N}$ latitude and $85^{\circ} 34^{\prime} 24.69^{\prime \prime}$ to $85^{\circ} 31^{\prime}$ $17.20 " \mathrm{E}$ longitude. The total area of Hariwon municipality is $86.08 \mathrm{sq} \mathrm{km}$ and 
elevation is $457 \mathrm{ft}$.The north of this municipality has Churia hills, which is $2 \mathrm{~km}$ away from the Mahendra highway. Geographically, north of Hariwon is dominated by tertiary unconsolidated and highly erodable sediments where sedimentary rocks, shale and conglomerate are common. In south, clay loam and silty clay are found. Most of the north of Hariwon is covered by community forest where Shorea robusta, Terminalia tomentosa, Acacia catechu, Asparagus recemosus, etc. are found. The open plain is agricultural land.

\section{Site III -Karmaya}

Karmaya is in the extreme north-west of Sarlahi.It is bordered by Patlaiya jungle in the west, Churia hills in the north and open plain agricultural land in the south and the east. It has an area of 35.928 square $\mathrm{km}$ and elevation of $455 \mathrm{ft}$. It lies between $27^{0}$ $06{ }^{\prime} 15.62^{\prime \prime}$ to $27^{0} 07^{\prime} 56.211^{\prime \prime} \mathrm{N}$ latitude and $85^{\circ}$ $31^{\prime} 21.52^{\prime \prime}$ to $85^{0} 28^{\prime} 59.88^{\prime \prime} \mathrm{E}$ longitude. Bagmati River makes a natural border and separates Sarlahi district from Rautahat district. Similar to the Hariwon, north of Karmaya VDC (Nunthar) has a sedimentary rock, shale and conglomerate, while southern land is covered by fine clay and silty clay. It has good irrigation facilities due to the presence Bagmati River.

\section{Climate}

Terai of Nepal experiences tropical climate with three distinct seasons, viz., summer (March - June), monsoon (July - October) and winter (November - February). Most of the part of Sarlahi is plain. The annual maximum temperature of Sarlahi is $31^{\circ} \mathrm{C}$ whereas annual minimum temperature is $20^{\circ} \mathrm{C}$. But sometimes, during summer season, temperature reaches $42^{\circ} \mathrm{C}$ and during winter season temperature falls to $4^{\circ} \mathrm{C}$. Almost $80 \%$ of the rainfalls in this district occur during the month of April to September.

\section{Materials and methods}

Different materials like digital camera (8 mega pixel), field diary, measuring tape, plastic bags, thread, gloves, hook stick, bag, forceps, syringe and needle, jar and 10\% formaldehyde were used.

For the collection of snake species, three sites were selected. They were Site-I (Lalbandi area), Site-II (Hariwon area) and Site-III (Karmaya area). All the sites were visited fortnightly and species were collected with the help of local people. For snake collection, visual encounter survey method was employed with regular visits to study sites and interaction with local people, teachers and students. The survey was conducted in all possible microhabitats such as shade, under boulder and logs, alongside of streams, agricultural field, forest, bushes and human settlements areas during day time from 9 am to $1 \mathrm{pm}$. People were encouraged to preserve killed snake specimens in $10 \%$ formalin or to give a call as soon as possible or to take photograph of any type of snake species found with digital camera or with the help of mobile camera in high resolution. The killed snake species were collected and preserved in 10\% formalin for further study. The collected snake specimens were identified by the standard books of Deoras (1965), Shrestha (2001), Daniel (2002), Schleich and Kastle (2002) Shah and Tiwari (2004), etc.

\section{Results}

Altogether 21 snake species were recorded (Table 1, Plate 1). These species belonged to 17 genera and 4 families. They represented the smallest bodied $(10 \mathrm{~cm})$ 
Krishna Chettri and Damodar Thapa Chhetry / Our Nature (2013), 11(2): 201-207

Table 1. List of snake species recorded from different study sites.

\begin{tabular}{|c|c|c|c|c|c|c|}
\hline S.N. & Scientific name & Common name & Nepali name & Site I & Site II & Site III \\
\hline 1 & $\begin{array}{l}\text { Ramphotyphlops } \\
\text { braminus } \\
\text { (Daudin, 1803) }\end{array}$ & $\begin{array}{l}\text { Brahminy worm } \\
\text { snake/Common } \\
\text { blind snake }\end{array}$ & $\begin{array}{l}\text { Andhara sarpa,Telya } \\
\text { sarpa,Ganeule sanp. }\end{array}$ & + & + & - \\
\hline 2 & $\begin{array}{l}\text { Typhlops diardii } \\
\text { (Schlegel,1839) }\end{array}$ & Diard's blind snake & Phusre telya sanp & + & - & - \\
\hline 3 & $\begin{array}{c}\text { Ahaetulla nasuta } \\
\text { (Lacepede, } 1789 \text { ) }\end{array}$ & Common vine snake & $\begin{array}{l}\text { Suga sanp,Udane } \\
\text { hareu }\end{array}$ & - & - & + \\
\hline 4 & $\begin{array}{l}\text { Amphiesma stolatum } \\
\text { (Linnaeus, 1758) }\end{array}$ & $\begin{array}{l}\text { Buff striped } \\
\text { keelback }\end{array}$ & $\begin{array}{l}\text { Bagala, Ashara, } \\
\text { Harara }\end{array}$ & + & + & + \\
\hline 5 & $\begin{array}{l}\text { Atretium schistosum } \\
\text { ((Daudan, 1803) }\end{array}$ & Olivaceous keelback & Panisanp & - & + & + \\
\hline 6 & $\begin{array}{l}\text { Boiga ochracea } \\
\text { (Gunther,1868) }\end{array}$ & $\begin{array}{l}\text { Common tawny cat } \\
\text { snake }\end{array}$ & Chudeu sarpa & - & + & + \\
\hline 7 & $\begin{array}{l}\text { Boiga trigonata } \\
\text { (Bechstein, 1802) }\end{array}$ & Common cat snake & $\begin{array}{l}\text { Adhoo sarpa,Tirishe, } \\
\text { Batasa }\end{array}$ & - & + & + \\
\hline 8 & $\begin{array}{l}\text { Dendrelaphis tristis } \\
\text { (Daudan,1803) }\end{array}$ & $\begin{array}{l}\text { Bronzeback tree } \\
\text { snake }\end{array}$ & Sirishe & - & + & - \\
\hline 9 & $\begin{array}{l}\text { Elaphe helena } \\
\text { (Daudin) }\end{array}$ & $\begin{array}{l}\text { Common trinket } \\
\text { snake }\end{array}$ & Singara sarpa & + & + & - \\
\hline 10 & $\begin{array}{l}\text { Enhydris enhydris } \\
\text { (Schneider,1799) }\end{array}$ & $\begin{array}{l}\text { Common smooth } \\
\text { water snake }\end{array}$ & $\begin{array}{l}\text { Panisanp, } \\
\text { Machhagidhi }\end{array}$ & + & + & + \\
\hline 11 & Lycodon aulicus & $\begin{array}{l}\text { Common wolf } \\
\text { snake }\end{array}$ & $\begin{array}{l}\text { Dhamiloo sarpa, } \\
\text { Buwasesarpa }\end{array}$ & + & + & - \\
\hline 12 & Lycodon jara & $\begin{array}{l}\text { Twin-spotted wolf } \\
\text { snake }\end{array}$ & Chichinde sarpa & - & - & + \\
\hline 13 & $\begin{array}{l}\text { Oligodon arnensis } \\
(\text { Shaw,1802) }\end{array}$ & $\begin{array}{l}\text { Common kukri } \\
\text { snake }\end{array}$ & Sankhad sanp & + & + & + \\
\hline 14 & $\begin{array}{l}\text { Ptyas mисоsa } \\
\text { (Linnaeus,1758) }\end{array}$ & Asiatic rat snake & Dhaman & + & + & + \\
\hline 15 & $\begin{array}{l}\text { Xenochrophis } \\
\text { piscator } \\
\text { (Schneider,1799) }\end{array}$ & $\begin{array}{l}\text { Chequered keelback } \\
\text { water snake }\end{array}$ & Panisanp, Dhodia sanp & - & + & + \\
\hline 16 & $\begin{array}{l}\text { Xenochrophis } \\
\text { sanctijohannis } \\
\text { (Bboulenger,1890) }\end{array}$ & $\begin{array}{l}\text { St.Jhon's keelback } \\
\text { water snake }\end{array}$ & $\begin{array}{l}\text { Panisanp, Dhodia } \\
\text { sarpa }\end{array}$ & - & + & - \\
\hline 17 & $\begin{array}{l}\text { Bungarus caeruleus } \\
\text { (Schneider,1801) }\end{array}$ & Common krait & Karet, Churia sarpa & + & + & + \\
\hline 18 & $\begin{array}{l}\text { Bangarus fasciatus } \\
\text { (Schneider,1801) }\end{array}$ & Banded krait & $\begin{array}{l}\text { Gangwari, } \\
\text { Panhelokalo Churia } \\
\text { sarpa }\end{array}$ & - & - & + \\
\hline 19 & $\begin{array}{l}\text { Naja naja } \\
\text { (Linnaeus, 1758) }\end{array}$ & Spectacled cobra & Goman, Nag & + & + & + \\
\hline 20 & $\begin{array}{l}\text { Ophiophagus hannah } \\
\text { (Cantor,1836) }\end{array}$ & King Cobra & Raj Goman & - & + & - \\
\hline 21 & $\begin{array}{l}\text { Daboia russelii } \\
\text { (Shaw and } \\
\text { Nodder,1797) }\end{array}$ & Russell's viper & Baghe sarpa & - & - & + \\
\hline Total & & & & 10 & 16 & 14 \\
\hline
\end{tabular}

Symbol: + indicates species encountered and - indicates species not encountered 


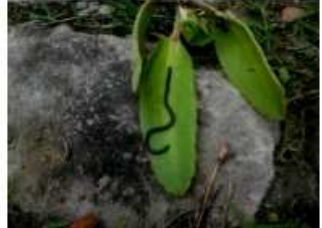

Ramphotyphlops

braminus

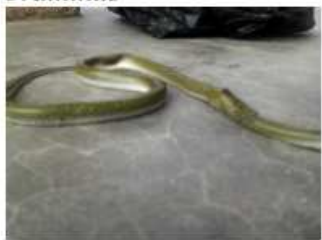

Atretium schistosum

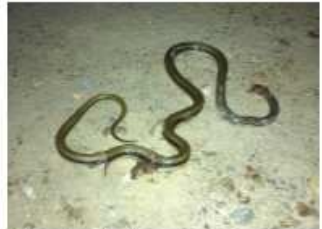

Elaphe helena

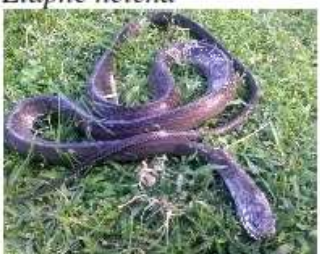

Ptyas тисова

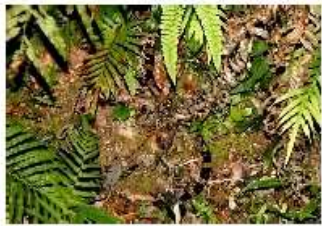

Bungarus fasciatus

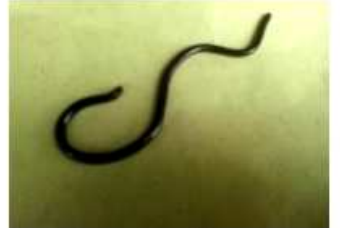

Typhlops diardii

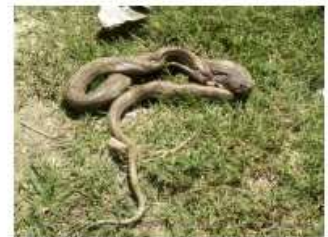

Boiga ochracea

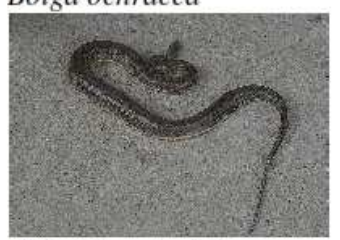

Enhydris enhydris

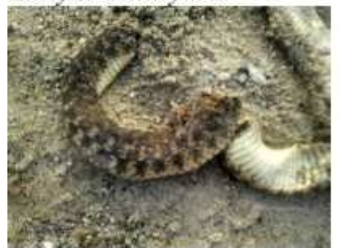

Xenochropis piscator

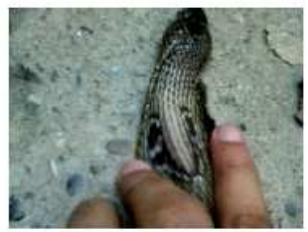

Naja naja

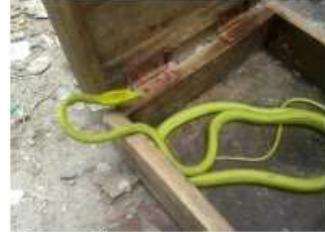

Ahaetulla nasuta

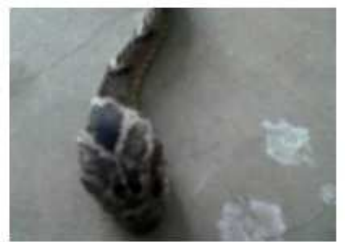

Boiga trigonata

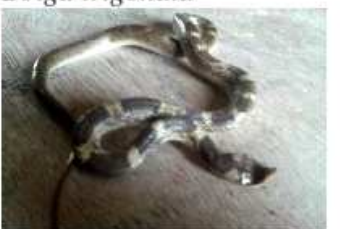

Lycodon aulicus

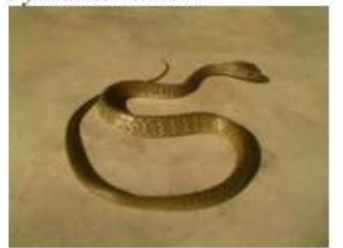

X. sanctijohannis

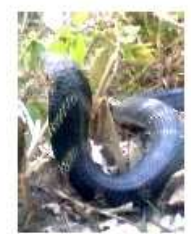

Ophiophagus hannah

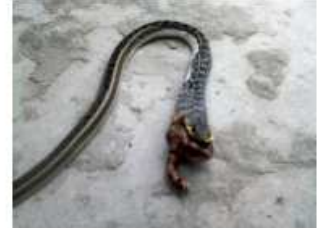

Amphiesma stolatum

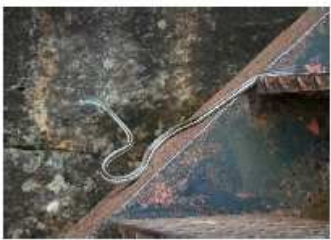

Dendrelaphis tristis

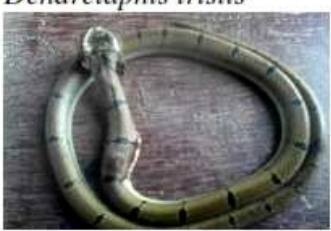

Oligodon arnensis

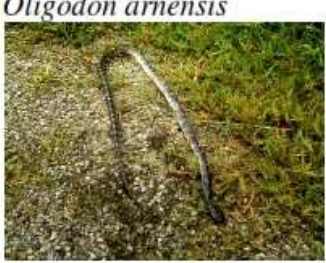

Bungarus caeruleus

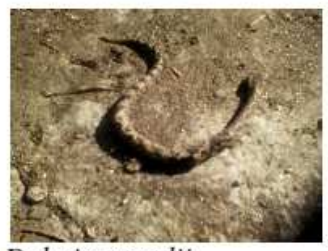

Daboia russelii

Plate 1. Photographs of snake species from different study sites.

blind snake to the long bodied $(175 \mathrm{~cm})$ rat snake. Out of 21 species, two were of Typhlopidae family, fourteen were of Colubridae, four belonged to Elapidae family and one was of Viperidae family. Out of fourteen colubrides, Elaphe helena is trinket snake, Ptyas mucosa is rat snake, Oligodon arnenis is kukri snake, Lycodon aulicus and Lycodon jara are wolf snakes, Dendrelaphis tristis is bronze back snake, Enhydris enhydris is mud snake, Amphiesma stolatum, Atretium schistosum, Xenochrophis piscator and Xenochrophis sanctijohannis are keelback snakes, Boiga trigonata and Boiga ochracea are cat snakes and Ahaetulla nasuta is whip snake. 
Ahaetulla nasuta, Enhydris enhydris, Boiga trigonata and Boiga ochracea are mild venomous while Bungarus caeruleus, Bungarus fasciatus, Naja naja, Ophiophagus hannah and Daboia russelii are highly venomous snakes of Nepal. Hence only five were highly venomous, four were mild venomous and the remaining twelve were non-venomous species. Out of 21 species recorded, 16 species were encountered from the Site II - Hariwon, 14 from Site III - Karmaya and 10 species were from Site I - Lalbandi (Table 1).

\section{Discussion}

There are about 3000 species of snakes found in the world, out of which 375 species $(12.5 \%)$ are poisonous (Sharma, 1999). Shah (1998) prepared a checklist of herpetofauna of Nepal in which he recorded 64 snake species. Shrestha, (2001) reported 90 species of snakes from Nepal, out of which 21 species are poisonous. However, no detail survey of the snake fauna of the country has been carried out so far. Nepalese snakes are divided into 5 families, out of which Typhlopidae, Boidae, and Colubridae are non-poisonous, while Elapidae and Viperidae are poisonous.

The present study recorded altogether 21 species belonging to 17 genera and four families. The four families are Typhlopidae, Colubridae, Elapidae and Viperidae. The snakes of Boidae family, recorded from other parts of Nepal, were not encountered in this area during the study period. Thapa and Thapa (2006) reported 14 species of snakes from Biratnagar area. Chhetry (2010) reported 6 species of snakes from Koshi Tappu Wildlife Reserve and its surroundings. Pandey (2010) recorded 31species from Chitwan National Park. At present survey, highest number of snake species was recorded from Site-II (Hariwon) and least number of snakes was recorded from site I (Lalbandi). In Hariwon, farmers cultivate the sugarcane in most of the land which provide good habitat for snakes. This may be the reason for the highest number of species recorded in this site. But, in Lalbandi, people are engaged in the cultivation of cash crop such as tomato, cauliflower, brinjal, etc. For these crops, they should plough and clean the land several times in a year and comparatively provide less suitable habitat for snake species. This may be the reason for lowest number of species recorded in Site I (Lalbandi).

Generally, people cannot distinguish the poisonous and non-poisonous snakes. They think every snake is poisonous. So, they kill snakes whenever they meet them. Thus, the snake species are decreasing day by day. For the conservation of snakes in Nepal, public awareness regarding the importance of snake to keep the ecosystem in balanced condition is essential.

\section{References}

Chhetry, D.T. 2010. Diversity of Herpetofauna in and around the Koshi Tappu Wildlife Reserve. Bibechana 6: 15-17.

Daniel, J.C. 2002. The Book of Indian Reptiles and Amphibians; Bombay Natural History Society 2002. Oxford University Press, India.

Deoras, P.J. 1965. Snakes of India. National Book Trust, New Delhi, India.

Fleming, R.L. Jr. and R.L. Fleming Sr. 1974. Some snakes from Nepal. J. Bombay Nat. Hist. Soc. No.3: 426-437.

Joshi, D.D.1985. Baseline Epidemiological Study on Snakebite Treatment and Management. Project report published by Zoonotic Disease Control Section, Dept. of Health Services, Ministry of Health, HMG, Nepal.

Kramer, U. 1977. Zur Schlangen fauna Nepals. Revue Suisse Zool. 84 (3): 721-761.

Nanhoe, L. M. R. and P. E. Ouboter 1987. The distribution of reptiles and amphibians in the 
Krishna Chettri and Damodar Thapa Chhetry / Our Nature (2013), 11(2): 201-207

Annapurna-Dhaulagiri region (Nepal). Zool. Verhandel, Leiden, Netherlands. 229: 1-66.

Orlov, N. and N. Helfenberger 1997. New mountain species of Trimeresurus (Serpentes, Viperidae, Crotalinae) of the "Green" pit viper group from the Himalayas. Russian J. of Herpetology. 4(2): 195-197.

Pandey, D.P. 2010. Snake in the Vicinity of Chitwan National Park. Sidhababa Oxford Press, Bharatpur, Nepal.

Schleich, H. H.1993.Contribution to the systematics and to a bibliography of the amphibians and reptiles from Nepal. J.of the Nepal Research Center IX: 141-168.

Schleich H.H. and W. Kaestle 2002. Amphibians and Reptiles of Nepal. A.R.G.Gantner Verlag K.G. Germany.

Shah, K.B.1995. Enumeration of the amphibians and reptiles of Nepal. Biodiversity Profiles Project. Publication No. 2. HMG, DNPWC, Kathmandu, Nepal.

Shah, K.B.1997. Amphibians and reptiles used as food and medicine in Nepal. A project report submitted to Tribhuvan University by Natural History Museum, Swayambhu, Kathmandu, Nepal.

Shah,K.B. 1998. Checklist of the herpetofauna of Nepal with English and Vernacular names. NAHSON bulletin. Nat. Hist. Soc. of Nepal. $8(1-$ 4):26-30.

Shah K.B. and M. K. Giri 1991. Habitat and distribution of some reptiles in Arun Basin, east Nepal. J. of Nat. Hist. Mus. 12(1-4): 61-70.

Shah, K.B., J.M. Shrestha and C.L.T. Thapa 2003. Snakebite Management Guideline. His Majesty's Government, Ministry of Health, Department of Health Services, Epidemiology and Diseases Control Divison, Kathmandu, Nepal.

Shah, K.B. and S. Tiwari 2004. Herpetofauna of Nepal. IUCN, Nepal.

Sharma, B.D.1999. Snakes: The Specialized Reptiles: in Sharma. In Snakes in India: a source book (Eds. B.D. Sharma and T.K. Kumari). Asiatic Publishing House, Delhi, India.

Shrestha, T.K. 2001. Herpetology of Nepal: a field guide to amphibian and reptiles of transhimalayan region of Asia. Mrs Bimala Shrestha, Kathmandu Nepal.

Swan, L.W. and A.E. Levitan 1962. The Herpetology of Nepal: A history, checklist and zoogeographical analysis of the herpetofauna. Proc.Calif.Acad.Sci., 32(6): 103-147.

Thapa, M. and R.B. Thapa 2006. Common Snakes of Biratnagar, Morang District, Nepal. In Natural Resource Management Ecological society (Eds. S.B. Karmacharya, M.R. Dhakal, S.N. Jha, T.N. Mandal, M.K. Chettri, B.R. Subba, U. Koirala, B. Niroula and K.P. Limbu), PG Campus, Biratnagar, Nepal Biological Society, Biratnagar and Ecological Society, Kathmandu,Nepal. pp.373383. 